\title{
PENGARUH FAKTOR PRIBADI TERHADAP KEPUTUSAN MAHASISWA FAKULTAS EKONOMI UNIVERSITAS TADULAKO MEMBELI SMARTPHONE XIAOMI
}

\author{
SITI FATIMA \\ JOHNNY TANAMAL \\ NIRWAN \\ Program StudiManajemen, FakultasEkonomiUniversitasTadulako \\ Email :imaalhabsy04@gmail.com, nirwan.fe.untad@gmail.com;
}

\begin{abstract}
The purpose of this study was to determine the Effect of Personal Factors on the Decision of the Students of the Faculty of Economics, Tadulako University, to buy a Xiaomi Smartphone in the City of Palu. The sampling technique uses incidental sampling with the number 75. The data used in this study are primary data obtained by providing a list of questions (questionnaire). The analytical method used is multiple linear regression analysis, $F$ test and t test. The results showed (1) the age variable and stage in the life cycle had a significant effect on the Decision of the Faculty of Economics Students of Tadulako University to buy a Xiaomi Smartphone in Palu City (2) the work variable had a significant effect on the Decision of the Faculty of Economics Students in Tadulako to buy a Xiaomi Smartphone in Palu City (3) lifestyle influences significantly on the Decision Faculty of Economics Students to buy a Xiaomi Smartphone in Palu City (4) personality variables and self-concept have a significant effect on the Decision of the Faculty of Economics Students in to buy a Xiaomi Smartphone in Palu City.
\end{abstract}

Keyword: Personal Factors, Student Decisions

\begin{abstract}
ABSTRAK
Tujuan penelitian ini ialah untuk mengetahuiPengaruhFaktor Pribadi Terhadap Keputusan Mahasiswa Fakultas Ekonomi Universitas Tadulako membeli Smartphone Xiaomi di Kota Palu. Teknik penarikan sampel menggunakan incidental sampling dengan jumlah 75. Data yang digunakan dalam penelitian ini adalah data primer yang diperoleh dengan memberikan daftar pertanyaan (kuesioner). Metode analisis yang digunakan yaitu analisis regresi linear berganda, uji $\mathrm{F}$ dan uji t. Hasil menunjukkan (1) variabel umur dan tahap dalam siklus hidup berpengaruh signifikan terhadap Keputusan Mahasiswa Fakultas Ekonomi membeli Smartphone Xiaomi di Kota Palu (2) variabel pekerjaan berpengaruh signifikan terhadap Keputusan Mahasiswa Fakultas Ekonomi Universitas Tadulako membeli Smartphone Xiaomi (3) gaya hidup berpengaruh signifikan pada Keputusan Mahasiswa Fakultas Ekonomi membeli Smartphone Xiaomi di Kota Palu (4) variabel kepribadian dan konsep diri berpengaruh signifikan terhadap Keputusan Mahasiswa Fakultas Ekonomi membeli Smartphone Xiaomi di Kota Palu.
\end{abstract}

Kata Kunci : Faktor Pribadi, Keputusan Mahasiswa

\section{PENDAhUluan}

Pada dasarnya teknologi informasi dan komunikasi saat ini sangat berkembang pesat, terutama dalam bidang komunikasi yaitu telepon seluler/handphone dan komputer yang dihubungkan dengan jaringan internet yang dapat digunakan sebagai alat untuk mempermudah seorang individu dengan individu lainnya tanpa ada batasan jarak dan waktu dalam berkomunikasi. Sebelum ada sosial media, sistem komunikasi yang berkembang di Indonesia masih menggunakan alat yang sederhana. Misalnya, dilakukan dengan peralatan media tradisional yaitu surat atau melalui komunikasi secara 
langsung. Lima tahun terakhir, Indonesia dikejutkan dengan pola komunikasi melalui HP. Media ini jelas akan mengubah perilaku komunikasi masyarakat.

Teknologi modern seperti, telekomunikasi sekarang ini telah melanda sendi - sendi kehidupan manusia terutama di Universitas Tadulako dimana penggunaan teknologi komunikasi membantu meringankan pekerjan. Beberapa faktor seperti budaya, pribadi, sosial, dan psikologis turut serta mempengaruhi Mahasiswa dalam mengambil keputusan pembelian alat telekomunikasi, yang dalam hal ini adalah Smartphone Xiaomi.

Universitas Tadulako merupakan perguruan tinggi negeri di Kota Palu yang memiliki 12 Fakultas yaitu Fakultas Keguruan dan Ilmu Pendidikan (FKIP), Fakultas Matematika dan Ilmu Pengetahuan Alam (FMIPA), Fakultas Pertanian (FAPERTA), Fakultas Teknik (FATEK), Fakultas Ilmu Sosial dan Ilmu Politik (FISIP), Fakultas Kehutanan (FAHUT), Fakultas Hukum (FAKUM), Fakultas Kedokteran (FK), Fakultas Kesehatan Masyarakat (FKM), Fakultas Peternakan dan Perikanan (FAPETKAN), dan Fakultas Ekonomi (FEKON)

\section{Tabel 1}

Data Mahasiswa Fakultas Ekonomi Tahun 2017-2018

\begin{tabular}{|c|c|c|}
\hline No & Jurusan/Prodi & Jumlah Mahasiswa \\
\hline 1. & Ekonomi Pembangunan/S1 & 1560 \\
\hline 2. & Ekonomi Manajemen/S1 & 1982 \\
\hline 3. & Ekonomi Akuntansi/S1 & 1866 \\
\hline 4. & Ekonomi Akuntansi/D3 & 220 \\
\hline 5. & Manajemen Pemasaran/D3 & 101 \\
\hline \multicolumn{2}{|r|}{ Jumlah } & 5729 \\
\hline
\end{tabular}

Sumber:Siakad Untad, 2018

Berdasarkan hasil observasi di Fakultas Ekonomi sebagianMahasiswa Fakultas Ekonomi Universitas Tadulako menggunakan Smartphone dengan berbagai merek yang berbeda-beda seperti Iphone, Samsung, Oppo Vivo dan lain-lain. Smartphone Xiaomi merupakan salah satu merek handphone yang diminati dikalangan Mahasiswa Fakultas Ekonomi. Berdasarkan pra/penelitian yang telah dilakukan pada 30 orang Mahasiswa Fakultas Ekonomi yang menggunakan Smartphone Xiaomi sebanyak 19 orang.

Perusahaan harus memahami perilaku konsumen, karena hal ini merupakan hal yang mutlak diperlukan dan terlebih lagi pada kondisi sekarang ini, dimana dalam era informasi dan persaingan semakin ketat maka diperlukan berbagai macam pendekatan. Namun disadari untuk memahami perilaku konsumen secara utuh bukanlah pekerjaan yang mudah, karena faktor yang mempengaruhi perilaku konsumen adalah sukar untuk ditentukan. Kesalahan dalam memahami perilaku konsumen merupakan awal dari kegagalan kegiatan pemasaran dimasa yang akan datang. Inovasi yang dilakukan oleh perusahaan untuk menghadapi pesaing dengan terus mengembangkan produk sehingga sangat banyak sekali produk sejenis yang menyebabkan konsumen harus berusaha memilih dari banyaknya merek produk yang bersaing. 
Faktor kepribadian ini tercermin pada usia dan tahap siklus hidup, yaitu keadaan yang menggambarkan riwayat manusia sejak awal tahun kehidupannya sampai dengan akhir kehidupannya, kemudian pekerjaan yaitu jenis mata pencarian yang menjadi sumber penghasilan seseorang dalam kehidupannya.Selanjutnya faktor pribadi juga tercermin pada gaya hidup yaitu pola hidup seseorang yang diekspresikan dalam aktifitas, minat dan opini, serta kepribadian dan konsep diri yaitu pola prilaku yang konsisten dan bertahan lama yang ada pada diri seseorang dan dinilai memiliki pengaruh terhadap perilaku konsumen dalam memutuskan membeli produk.Berdasarkan pemahaman diatas, maka penulis tertarik meneliti tentang Pengaruh Faktor Pribadi Terhadap Keputusan Mahasiswa Fakultas Ekonomi Universitas Tadulako Membeli Smartphone Xiaomi di Kota Palu.

\section{KAJIAN LITERATURE DAN PENGEMBANGAN HIPOTESIS}

Terdapat bebarapa faktor yang mempengaruhi perilaku konsumen, yaitu (Setiadi, (2010:10-14)):

1. Faktor Kebudayaan

a) Kebudayaan merupakan faktor penentu yang paling mendasar dari keinginan dan perilaku seseorang.

b) Subbudaya, setiap kebudayaan terdiri dari subbudaya-subbudaya yang lebih kecil yang memberikan identifikasi dan sosialisasi yang lebih spesifik untuk para anggotanya.

c) Kelas sosialadalah kelompok yang relatif homogen dan bertahan lama dalam suatu masyarakat, yang tersusun secara hierarki dan keanggotaanya mempunyai nilai, minat dan perilaku yang serupa.

2. Faktor Sosial

a) Kelompok referensi, terdiri dari seluruh kelompok yang mempunyai pengaruh langsung maupun tidak langsung terhadap sikap atau perilaku seseorang.

b) Keluarga, kita dapat menggolongkan dua keluarga dalam kehidupan pembeli yaitu (1) keluarga orientasi, yang merupakan orang tua seseorang. (2) keluarga prokpreasi, yaitu pasangan hidup anak-anak seseorang.

3. Faktor pribadi

a) Umur dan tahap dalam siklus hidup, orang-orang dewasa biasanya mengalami perubahan atau transformasi tertentu pada saat mereka menjalani kehidupan.

b) Pekerjaan, para pemasar berusaha mengidentifikasi kelompok-kelompok pekerja yang memiliki minat diatas rata-rata terhadap produk jasa.

c) Gaya hidup, adalah pola hidup didunia yang diekspresikan oleh kegiatan, minat dan pendapat seseorang.

d) Kepribadian dan konsep diri, adalah katrakteristik psikologi yang berbeda dari setiap orang yang memandang responnya tergadap lingkungan yang relatif konsisten.

4. Faktor Psikologis

a) Motivasi, beberapa kebutuhan bersifat biogenic, kebutuhan ini timbul dari suatu keadaan psikologis tertentu seperti rasa lapar, haus dan tidak nyaman.

b) Persepsi, didefenisikan sebagai proses dimana seseorang memilih, mengorganisasikan, mengartikan masukan informasi untuk menciptakan suatu gambaran yang berarti dari dunia ini.

c) Proses belajar, menjelaskan perubahan dalam prilaku seseorang yang timbul dari pengalaman.

Sedangkan menurut Danang Sunyoto (2013:13) perilaku konsumen untuk melakukan pembelian dipengaruhi oleh:

a. Faktor Budaya, Budaya adalah penyebab paling mendasar dari keinginan dan perilaku seseorang. 
b. Faktor Kelas Sosial, Kelas sosial adalah perilaku yang dipengaruhi oleh kelompok kecil, keluarga, serta peran dan status sosial konsumen.

c. Faktor Keluarga, Keluarga dapat didefinisikan sebagai suatu unit masyarakat yang terkecil yang perilakunya sangat memengaruhi dan menentukan dalam pengambilan keputusan membeli.

d. Faktor Pengaruh Pribadi, Keputusan pembelian juga dipengaruhi oleh faktor pribadi seperti umur dan tahapan daur hidup, pekerjaan, situasi ekonomi, gaya hidup, serta kepribadian dan konsep diri pembeli.

\section{KerangkaPemikiran}

Pada dasarnya perilaku konsumen adalah merupakan proses keputusan. Hal ini diakibatkan karena walaupun didasari bahwa sesungguhnyan perilaku tersebut akan sangat dipengaruhi oleh faktor yang berasal dari luar, namun pada gilirannya dalam menetapkan keputusan akan didomiasi oleh faktor yang ada dalam diri seseorang, sehingga dapat ditarik sebuah kesimpulan bahwa sesungguhnya perilaku konsumen adalah merupakan salah satu indikator keputusan yang ditentukan seseorang sebelum menetapkan keputusan untuk membeli atau menggunakan barang atau jasa yang di inginkan. Bagi suatu organisasi perusahaan yang memproduksi barang atau jasa perlu untuk memahami perilaku tersebut, karena dalam menentukan keputusan membeli dan menggunakan suatu produk, seseorang akan dipengaruhi oleh kondisi intern dan ekstern yang memungkinkan perilaku tersebut dapat berubah ubah setiap saat.

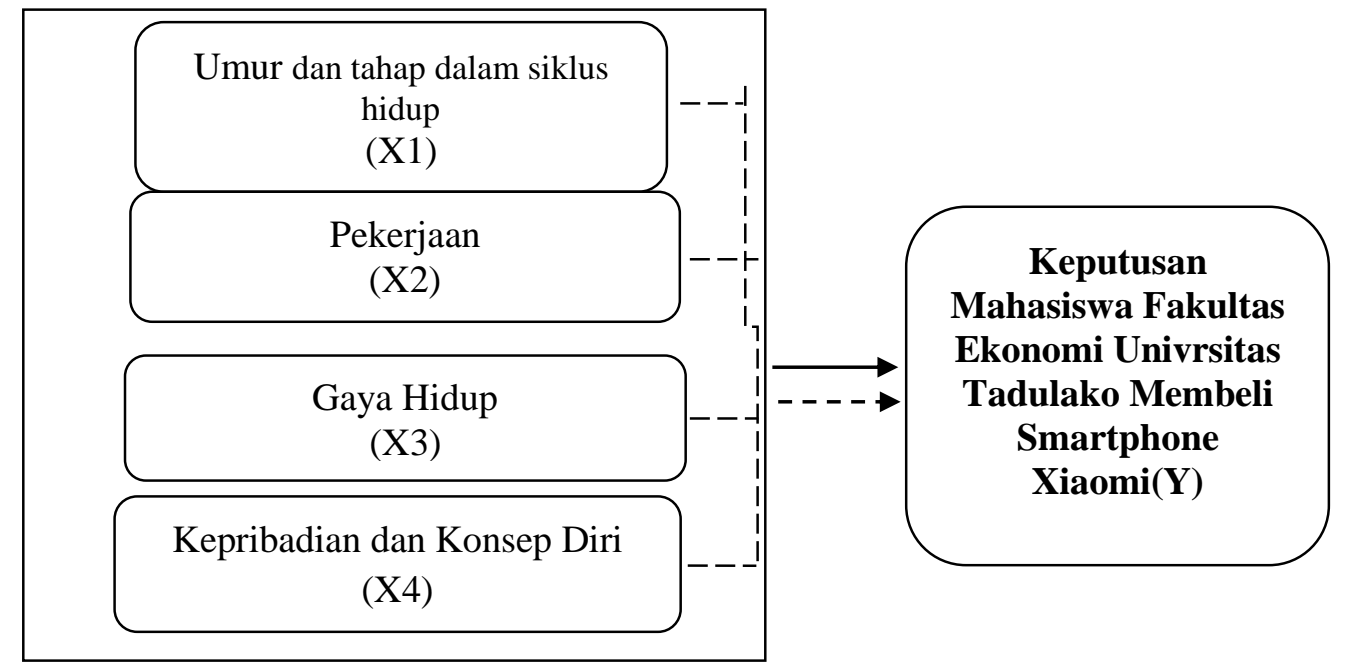

Keterangan :

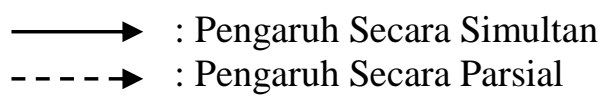

\section{Hipotesis}

\section{Gambar 2}

\section{Kerangka Pemikiran}

Berdasarkan rumusan masalah dan landasan teori yang telah dikemukakan maka dapat disusun hipotesis penelitian sebagai berikut :

1. Faktor pribadi yang terdiri dari variabel umur dan tahap siklus hidup, variabel pekerjaan, variabel gaya hidup dan variabel kepribadian dan konsep diri secara serempak berpengaruh signifikan terhadap keputusan Mahasiswa Fakultas Ekonomi Universitas Tadulako membeli SmartPhone Xiaomi di Kota Palu 
2. Variabel Umur dan tahap siklus hidup secara parsial berpengaruh signifikan pada keputusan Mahasiswa Fakultas Ekonomi Universitas Tadulako membeli SmartPhone Xiaomi.

3. Variabel Pekerjaan secara parsial berpengaruh signifikan terhadap keputusan Mahasiswa Fakultas Ekonomi Universitas Tadulako membeli SmartPhone Xiaomi di Kota Palu

4. Variabel Gaya hidup secara parsial berpengaruh signifikan terhadap keputusan Mahasiswa Fakultas Ekonomi Universitas Tadulako membeli SmartPhone Xiaomi di Kota Palu

5. Variabel Kepribadian dan konsep diri secara parsial berpengaruh signifikan terhadap keputusan Mahasiswa Fakultas Ekonomi Universitas Tadulako membeli SmartPhone Xiaomi di Kota Palu.

\section{METODE PENELITIAN}

\section{Jenis Penelitian}

Penelitian ini menggunakan jenis penelitian deskriptif kausal.Menurut Travers (dalam Umar, 2003:87) metode deskriptif merupakan suatu metode yang bertujuan untuk menggambarkan sifat sesuatu yang tengah berlangsung pada saat riset dilakukan dan memeriksa sebab-sebab dari suatu gejala tertentu. Kausal adalah penelitian yang bertujuan untuk mengetahui hubungan antara dua variabel atau lebih, atau bagimana suatu variabel mempengaruhi variabel lain.Deskrtiptif kausal yaitu mengetahui secara langsung pengaruh variabel perilaku konsumen yang terdiri dari (budaya, sosial, pribadi dan psikologi), dan keputusan mahasiswa membeli membeli ponsel Xiaomi di Kota Palu.

\section{Populasi dan Teknik Penarikan Sampel}

a). Populasi

Populasi adalah wilayah generalisasi yang terdiri atas obyek/subyek yang mempunyai kualitas dan karakteristik tertentu yang ditetapkan oleh peneliti untuk dipelajari dan kemudian ditarik kesimpulannya (Sugiyono,2014;61).Berdasarkan jumlah data mahasiswa Fakultas Ekonomi Universitas Tadulako sebanyak 5.729 mahasiswa. Namun demikian, data tersebut tidak dapat dijadikan populasi karena tidak ada data mahasiswa yang menggunakan smarthphone xiaomi. Maka jumlah populasi dalam penelitian ini tidak dapat diketahui secara pasti.

b). Teknik Penarikan sampel

Karena Populasi tidak dapat diketahui maka peneliti memakai teknik penarikan sampel nonprobability sampling dengan teknik sampling incidental. Dimana menurut Sugiyono (2015:96) Sampling Incidental adalah teknik penentuan sampel secara kebetulan, yaitu siapa saja yang secara kebetulan/Incidental bertemu dengan peneliti dapat digunakan sebagai sampel, bila dipandang orang yang kebetulan ditemui itu cocok sebagai sumber data.

Untuk menentukan besar sampel peneliti merujuk pada teori Roscoe (dalam Sugiyono 2014:102,103) bila dalam penelitian akan melakukan analisis dengan multivariate (korelasi atau regresi berganda misalnya), maka jumlah anggota sampel minimal 10 kali dari jumlah variabel yang diteliti (independen + dependen). Jumlah variabel dalam penelitian ini adalah 4 variabel independen yaitu variabel faktor pribadi yang terdiri dari (Umur dan tahap dalam siklus hidup, Pekerjaan, Gaya hidup, Kepribadian dan konsep diri) dan 1 variabel dependen (keputusan pembelian). Berdasarkan pertimbangan tersebut maka penulis menetapkan jumlah sampel dengan ketentuan $15(4+1)$ variabel yaitu 75 responden.

\section{Defenisi Operasional Variabel}

1.Variabel Umur dan Tahap Siklus Hidup $\left(\mathrm{X}_{1}\right)$ 
Maksud dari variabel ini adalah batasan usia atau tahapan siklus hidup mahasiswa fakultas ekonomi universitas tadulako yang berperan memberikan pengaruh untuk memiliki smartphone xiaomi.Adapun indikator dari variabel ini adalah:

a) Mampu menyesuaikan diri dengan teknologi smartphone

b) Mudah mempelajari spesifikasi smartphone

c) Konsisten terhadap merek smartphone

d) Mudah mengoprasikan smartphone

2. Variabel Pekerjan $\left(\mathrm{X}_{2}\right)$

Pekerjan adalah suatu kegiatan atau aktifitas yang menghasilkan sejumlah pendapatan mahasiswa di cela-cela perkuliahannya, yang dinilai memberi pengaruh terhadap keputusan mahasiswa membeli smartphone xiaomi. Adapun indikator dari variabel ini adalah:
a) Memanfaatkan waktu luang
b) Kelebihan pendapatan
c) Membantu aktifititas sehari-hari

3. Variabel Gaya Hidup $\left(\mathrm{X}_{3}\right)$

Gaya hidup yang mencerminkan cara hidup mahasiswa terhadap lingkungan sekitar yang terungkap pada kegiatan, minat dan opininya yang dinilai memberi pengaruh pada keputusan mahasiswa membeli smartphone xiaomi. Adapun indikator dari variabel ini adalah:
a) Mengikuti trend
b) Keinginan/minat sendiri
c) Keterlibatan promosi
d) Keterlibatan teman
e) Keterlibatan keluarga
f) Penilaian khusus

4. Variabel Kepribadian dan Konsep Diri $\left(\mathrm{X}_{4}\right)$

Kepribadian dan konsep diri mencerminkan sifat psikologis mahasiswa yang konsisten baik menurut penilaian secara individu maupun penilaian orang lain yang dinilai memberi pengaruh pada keputusan mahasiswa membeli smartphone xiaomi.Adapun indikator dari variabel ini adalah:
a) Percaya diri
b) Kebutuhan produk
c) Kemudahan berkomunikasi
d) Mengikuti pengalaman orang
e) Percaya dengan kualitas produk

\section{Metode Analisis}

Untuk menjawab permasalahan serta hipotesis yang diajukan digunakan alat analisis statistik, yaitu Regresi Berganda (Multiple Linear Regression).Adapun penggunaan regresi linear berganda terkait dengan permasalahan dan hipotesis yang diajukan dalam penelitian pengaruh variable independen (X) terhadap variable dependen (Y) melalui bantuan SPSS 16.0.

\section{HASIL DAN PEMBAHASAN}

\section{Hasil}

Berikut hasil mengenai pengaruh variabel bebas baik secara serempak maupun parsial yang diolah SPSS 16. Adapun penggunaan regresi linear berganda terkait dengan permasalahan dan hipotesis yang diajukan dalam penelitian pengaruh variabelin dependen $(\mathrm{X})$ terhadap variable dependen $(\mathrm{Y})$, dengan analisis regresi linier berganda seperti pada tabel 2 berikut ini: 
Tabel 2

Hasil Analisis Regresi Linier Berganda

\begin{tabular}{|c|c|c|c|c|}
\hline \multirow{2}{*}{ Variabel Independen } & \multicolumn{2}{|c|}{$\begin{array}{c}\text { Unstandardized } \\
\text { Coefficients }\end{array}$} & $\begin{array}{c}\text { Standardized } \\
\text { Coefficients }\end{array}$ & Sig t \\
\cline { 2 - 5 } & B & Std. Error & Beta & \\
\hline C = Constanta & 2.011 & 0,261 & & 0,000 \\
\hline Usia dan Tahap Siklus Hidup $\left(\mathrm{X}_{1}\right)$ & 0,209 & 0,043 & 0,378 & 0,000 \\
\hline Pekerjaan $\left(\mathrm{X}_{2}\right)$ & 0,116 & 0,043 & 0,277 & 0,009 \\
\hline Gaya Hidup $\left(\mathrm{X}_{3}\right)$ & 0,130 & 0,049 & 0,263 & 0,011 \\
\hline Kepribadian dan Konsep Diri $\left(\mathrm{X}_{4}\right)$ & 0,117 & 0,054 & 0,265 & 0,033 \\
\hline Multiple $\mathrm{R}$ & $=0,757$ & \multicolumn{3}{c}{ Adjusted R Square $=0,548$} \\
\hline R Square $=0,573$ & & \multicolumn{3}{c}{} \\
\hline
\end{tabular}

Sumber: Data diolah, 2018

\section{Pembahasan}

1. Pengaruh Variabel Usia dan Tahap Siklus Hidup $\left(\mathrm{X}_{1}\right)$

Berdasarkan hasil pengujian seperti yang terlihat pada tabel hasil analisis regresi linier berganda (Tabel 5.9) di atas, nilai probabilitas signifikansi t (usia dan tahap siklus hidup) lebih kecil dari nilai $\alpha$ $(0,003<0,05)$ maka hipotesis diterima dalam penelitian ini yaitu usia dan tahap siklus hidup secara parsial berpengaruh signifikan terhadap Keputusan Mahasiswa Fakultas Ekonomi Universitas Tadulako Membeli Smartphone Xiaomi Kota Palu dengan pengaruh sebesar 0,378.

2. Pengaruh Variabel Pekerjaan $\left(X_{2}\right)$

Berdasarkan hasil pengujian seperti yang terlihat pada tabel hasil analisis regresi linier berganda (Tabel 5.11) di atas, nilai probabilitas signifikansi t $\mathrm{X}_{2}$ (pekerjaan) lebih kecil dari nilai $\alpha(0,02<0,05)$ maka hipotesis diterima dalam penelitian ini yaitu pekerjaan secara parsial berpengaruh signifikan terhadap Keputusan Mahasiswa Fakultas Ekonomi Universitas Tadulako Membeli Smartphone Xiaomi Kota Palu dengan pengaruh sebesar 0,277.

3. PengaruhVariabel Gaya Hidup $\left(\mathrm{X}_{3}\right)$

Berdasarkan hasil pengujian seperti yang terlihat pada tabel hasil analisis regresi linier berganda (Tabel 5.11) di atas, nilai probabilitas signifikansi t X3 (gaya hidup) lebih kecil dari nilai $\alpha(0,0023<$ 0,05). Dengan demikian, maka hipotesis diterima dalam penelitian ini yaitu gaya hidupsecara parsial berpengaruh signifikan terhadap Keputusan Mahasiswa Fakultas Ekonomi Universitas Tadulako Membeli Smartphone Xiaomi Kota Palu dengan pengaruh sebesar 0,263.

4. Pengaruh Variabel Kepribadian dan Konsep Diri $\left(\mathrm{X}_{4}\right)$

Berdasarkan hasil pengujian seperti yang terlihat pada tabel hasil analisis regresi linier berganda (Tabel 5.11) di atas, nilai probabilitas signifikansi t $\mathrm{X}_{4}$ (kepribadian dan konsep diri) lebih kecil dari nilai $\alpha(0,027<0,05)$ maka hipotesis diterima dalam penelitian ini yaitu act secara parsial berpengaruh signifikan terhadap Keputusan Mahasiswa Fakultas Ekonomi Universitas Tadulako Membeli Smartphone Xiaomi Kota Palu dengan pengaruh sebesar 0,265.

\section{KESIMPULAN DAN SARAN}

\section{Kesimpulan}

Berdasarkan hasil dan pembahasan penelitian pada bab sebelumnya, maka penulis dapat mengambil beberapa kesimpulan darihasil penelitin ini sebagai berikut:

1) Hasil pengujian hipotesis pertama penelitian, membuktikan secara empiris dan ilmiah bahwa variabel pribadi yang terdiri dari dimensi usia dan tahap siklus hidup, pekerjaan, gaya hidup, 
kepribadian dan konsep diri, secara simultan berpengaruh signifikan terhadap keputusan mahasiswa Fakultas Ekonomi Universitas Tadulako membeli Smartphone Xiaomi di Kota Palu.

2) Hasil pengujian hipotesis kedua penelitian, membuktikan secara empiris dan ilmiah bahwa variable usia dan tahap siklus hidup berpengaruh signifikan terhadap keputusan mahasiswa Fakultas Ekonomi Universitas Tadulako membeli Smartphone Xiaomi di Kota Palu.

3) Hasil pengujian hipotesis ketiga penelitian, membuktikan secara empiris dan ilmiah bahwa variable pekerjaan berpengaruh signifikan terhadap keputusan mahasiswa Fakultas Ekonomi Universitas Tadulako membeli Smartphone Xiaomi di Kota Palu.

4) Hasil pengujian hipotesis keempat penelitian, membuktikan secara empiris dan ilmiah bahwa variable kepribadian berpengaruh signifikan terhadap keputusan mahasiswa Fakultas Ekonomi Universitas Tadulako membeli Smartphone Xiaomi di Kota Palu.

5) Hasil pengujian hipotesis kelima penelitian, membuktikan secara empiris dan ilmiah bahwa variable kepribadian dan konsep diri berpengaruh signifikan terhadap keputusan mahasiswa Fakultas Ekonomi Universitas Tadulako membeli Smartphone Xiaomi di Kota Palu.

\section{Saran}

Berdasarkan kesimpulan di atas, maka penulis dapat memberikan beberapa saran sebagai berikut:

1) Manfaat produk bagi pelanggan harus lebih ditingkatkan melalui inovasi produk-produk baru sehingga lebih mempengaruhi keputusan konsumen membeli smartphone xiaomi

2) Keandalan produk harus lebih ditingkatkan melalui pemanfaatan teknologi terkini sehingga lebih mempengaruhi minat membeli kembali calon konsumen smartphone xiaomi

3) Diharapkan pula di masa-masa mendatang, perusahaan atau agen distributor smartphone xiaomi terus mengembangan variasi tipe smartphone yang dipasarkan.dengan model dan fitur fitur yang canggih.

4) Penelitian selanjutnya, diharapkan untuk mencari, menambahkan, atau bahkan mengkombinasikan variabel-variabel independen lainnya selain yang dilakukan peneliti, yang tentunya dapat mempengaruhi variabel dependen keputusankonsumenagar lebih melengkapi penelitian ini karena masih ada variabel-variabel independen lain di luar penelitian ini yang mungkin bisa mempengaruhi keputusantersebut.

\section{REFERENSI}

Danang Sunyoto, (2015). PerilakuKonsumendanPemasaran. CAPS, Yogyakarta.

Kotler, Philip, dan Keller, 2009, ManajemenPemasaran, Terjemahan Benyamin Molan, EdisiKetigaBelas, Jilid I, Erlangga, Ciracas, Jakarta.

Sugiyono. (2014). MetodePenelitianBisnis (PendekatanKuantitatif, Kualitatifdan R\&D. Bandung: Alfabeta.

Sugiyono. (2015), MetodePenelitianAdministrasi. Bandung Alfabeta.

Setiadi, Nugroho J. (2005). PerilakuKonsumen: PerspektifKontenprorerPada Motifasi Tujuan, Dan

KeinginanKonsumen, PenerbitKencana. 